\title{
Introduction to Planetary Geology
}

\section{B.P. GLASS}

This is a comprehensive introductory textbook to the entire field of planetary geology, which takes into account the findings of all the major landings and deep space missions: Apollo, Mariner, Viking and Voyager. Handsomely illustrated, including dramatic full-colour plates, the book considers all the planets, satellites, asteroids and comets, with emphasis on the nature of their surfaces, internal compositions and structures, formation and geological history.

£18.00 net

\section{A History of Persian Earthquakes}

\section{N.N. AMBRASEYS and C. MELVILLE}

This study of the historical seismicity of Iran over the last thirteen centuries shows that areas of intense seismic activity in the past are often gaps of earthquake activity today and also reveals a long-term tectonic pattern which is different from that deduced from short-term observations. The data provide the basis for the development of earthquake prediction models and long-term hazard assessment. £35.00 net

\section{A Geologic Time Scale}

\section{W.B. HARLAND et al.}

A concentrated review of the state of chronostratigraphic, chronometric and other scales including a revised calibration in years of the standard stratigraphic scale. Following an introduction the book contains the stratigraphic time scale and correlation charts, a new way of presenting data for age estimates of each boundary (chronograms), a new magnetostratigraphic time scale, and a summary of world events in the form of a chart

Hard covers about $\mathbf{1} 12.50$ net

\section{Wallchart for a Geologic Time Scale}

\section{W.B. HARLAND et al.}

This coloured wallchart summarises the contents of the above book There are columns for stratigraphic divisions, estimated chronometric values, magnetic reversal scale, eustatic curve and sundry world events.

Rolled unfolded E2.95 net + VAT in UK Folded E2.25 net + VAT in UK

\section{CAMBRIDGE UNIVERSITY PRESS}



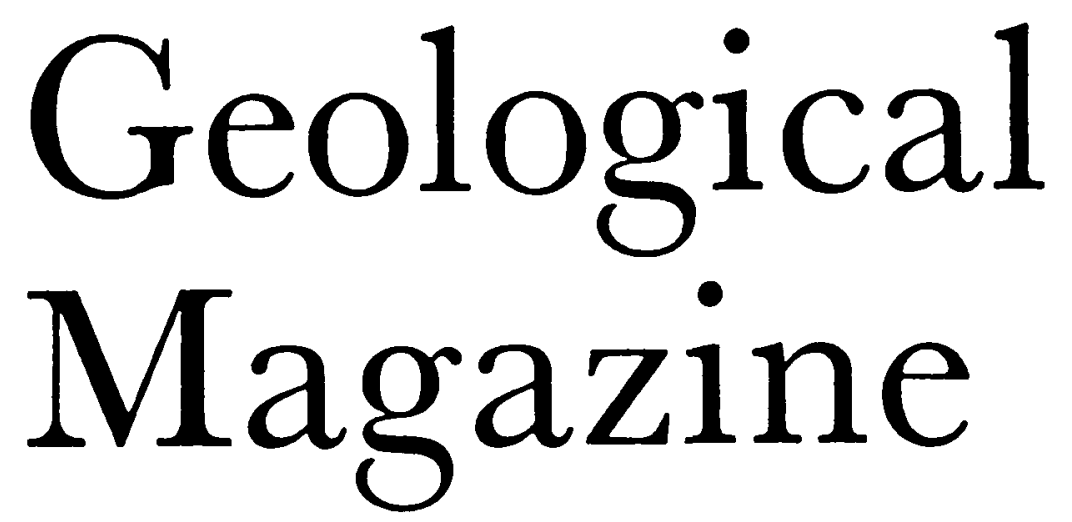

with which is incorporated

\section{The Geologist}

founded in 1864 by the late DR HENRY wOODWARD, F.R.S.

Edited by W. B. HARLAND, M.A.

C. P. HUGHES, M.A.

and R. S. J. SPAR KS, M.A.

assisted by MRS M. J. MASON

Associate editors

SIR KINGSLEY DUNHAM, D.SC., F.R.S.

MR N. L. FALCON, M.A., F.R.S.

SIR PETER KENT, D.SC., F.R.S.

PROFESSOR F. W. SHOTTON, M.B.E., M.A., SC.D., F.R.S.

SIR JAMES STUBBLEFIELD, D.SC., F.R.S.

Volume I 19 of Whole Series

January-December 1982

\section{CAMBRIDGE UNIVERSITY PRESS \\ CAMBRIDGE \\ LONDON NEW YORK NEW ROCHELLE \\ MELBOURNE SYDNEY}




\section{PUBLISHED BY}

THE PRESS SYNDICATE OF THE UNIVERSITY OF CAMBRIDGE

The Pitt Building, Trumpington Street, Cambridge CB2 1RP

32 East 57th Street, New York, N.Y. 10022

(C) Cambridge University Press 1982

Pagination and dates of publication of issues in this volume

$\begin{aligned} \text { Number 1: pp. 1-112 } & \text { January } 1982 \\ \text { 2: pp. 113-228 } & \text { March 1982 } \\ \text { 3: pp. 229-336 } & \text { May 1982 } \\ \text { 4: pp. 337-432 } & \text { July 1982 } \\ \text { 5: pp. 433-526 } & \text { September } 1982 \\ \text { 6: pp. 527-642 } & \text { November } 1982\end{aligned}$

Printed in Great Britain at the University Press Cambridge 


\section{Contents}

\section{ART ICLES}

(Figures in bold type denote number of issue)

BENKHELIL, J.

Benue Trough and Benue Chain, 2, 155

BLACKNELL, C.

Morphology and surface sedimentary features of point bars in Welsh gravel-bed rivers, 2, 181

BRADSHAW, M. J. \& PENNEY, S. R.

A cored Jurassic sequence from north Lincolnshire, England: stratigraphy, facies analysis and regional context, 2, 113

CAMPBELL, I. H. \& ARNDT, N. T.

Pyroxene accumulation in spinifex-textured rocks, 6, 605

CHOWDHURY, A. N.

Smectite, zeolite, biotite and apatite in the Corallian (Oxfordian) sediments of the Baulking area in Berkshire, England, 5, 487

CLOUGH, B. J., WRIGHT, J. V. \& WALKER, G. P. L.

Morphology and dimensions of the young comendite lavas of La Primavera volcano, Mexico, 5, 477

CRAIG, J., FITCHES, W. R. \& MALTMAN, A. J.

Chlorite-mica stacks in low-strain rocks from central Wales, 3, 243

DONOVAN, S. K. \& PAUL, C. R. C.

Lower Cambrian echinoderm plates from Comley, Shropshire, England, 6, 611

ELLIOTT, G. F.

Calcareous algae and Middle Jurassic facies of southern England, 3, 309

FISHER, P. \& ROLLS, J. D.

A thermokarst phenomenon on a terrace of the Rivey Wey near Farnham, Surrey, England, 3, 315

FRENCH, C. A. I.

An analysis of the molluscs from an Ipswichian interglacial river channel deposit at Maxey, Cambridgeshire, England, 6, 593

GREEN, C. P., McGREGOR, D. F. M. \& EVANS, A. H.

Development of the Thames drainage system in early and middle Pleistocene times, $\mathbf{3}$, 281

GUPTA, A., BASU, A. \& GHOSH, P. K.

Ultramafic volcaniclastics of the Precambrian Dalma Volcanic Belt, Singhbhum, Eastern India, 5, 505

HAMBREY, M. J.

Late Precambrian diamictites of northeastern Svalbard, 6, 527

HOLDAWAY, H. K. \& CLAYTON, C. J.

Preservation of shell microstructure in silicified brachiopods from the Upper Cretaceous Wilmington Sands of Devon, 4, 371 
IMEOKPARIA, E. G.

Geochemistry and relationships to mineralization of granitic rocks from the Afu Younger Granite Complex, Central Nigeria, 1, 39

JEFFERSON, T. H.

The preservation of fossil leaves in Cretaceous volcaniclastic rocks from Alexander Island, Antarctica, 3, 291

JENKINS, D. G.

The age and palaeoecology of the St Erth Beds, southern England, based on planktonic foraminifera, 2, 201

KNOLL, A. H.

Microfossil-based biostratigraphy of the Precambrian Hecla Hoek sequence, Nordaustlandet, Svalbard, 3, 269

KOKELAAR, B. P., FITCH, F. J. \& HOOKER, P. J.

A new $\mathrm{K}-\mathrm{Ar}$ age from uppermost Tremadoc rocks of north Wales, 2, 207

LIPPARD, S. J. \& REX, D. C.

$\mathrm{K}-\mathrm{Ar}$ ages of alkaline igneous rocks in the northern Oman mountains, NE Arabia, and their relations to rifting, passive margin development and destruction of the Oman Tethys, 5, 497

MCDOUGALL, I. \& OLLIER, C. D.

Potassium-argon ages from Tristan da Cunha, South Atlantic, 1, 87

MEREFIELD, J. R.

Modern carbonate marine-sands in estuaries of southwest England, 6, 567

MORTON, A. C.

Heavy minerals of Hampshire Basin Palaeogene strata, 5, 463

O'CONNOR, P. J., HENNESSY, J., BRÜCK, P. M. \& WILLIAMS, C. T.

Abundance and distribution of uranium and thorium in the northern units of the Leinster granite, Ireland, 6, 581

OWENS, R. M., FORTEY, R. A., COPE, J. C. W., RUSHTON, A. W. A. \& BASSETT, M. G.

Tremadoc faunas from the Carmarthen district, south Wales, 1, 1

PE-PIPER, G., PANAGOS, A. G., PIPER, D. J. W. \& KOTOPOULI, C. N.

The (?) mid Triassic volcanic rocks of Lakonia, Greece, 1, 77

PLATTEN, I. M.

A late Caledonian breccia dyke swarm in Glen Creran, near Glen Coe in the Grampian Highlands, 2, 169

PLATTEN, I. M.

Partial melting of feldspathic quartzite around late Caledonian minor intrusions in Appin, Scotland, 4, 413

PRICE, D.

Calymene quadrata King, 1923 and allied species of trilobites from the Ashgill Series of north Wales, 1, 57

PYE, K.

Characteristics and significance of some humate-cemented sands (humicretes) at Cape Flattery, Queensland, Australia, 3, 229 
RAWSON, P. E.

New Arctocephalitinae (Ammonoidea) from the Middle Jurassic of Kong Karls Land, Svalbard, 1, 95

REYMER, A. P. S.

Indirect dating of tectonic events by $\mathrm{Rb}-\mathrm{Sr}$ analysis of syntectonic garnets: an example from schists of the Seve Nappe, central Scandinavian Caledonides, 6, 599

RICKARDS, R. B., CROWTHER, P. R. \& CHAPMAN, A. J.

Ultrastructural studies of graptolites - a review, 4, 355

ROSS, R. J., JR, NAESER, C. W., IZETT, G. A., OBRADOVICH, J. D., BASSETT, M. G., HUGHES, C. P., COCKS, L. R. M., DEAN, W. T., INGHAM, J. K., JENKINS, C. J., RICKARDS, R. B., SHELDON, P. R., TOGHILL, P., WHITTINGTON, H. B. \& ZALASIEWICZ, J.

Fission-track dating of British Ordovician and Silurian stratotypes, 2, 135

SAMANTA, B. K.

Fabiania Silvestri (Foraminiferida) from India, with notes on its global distribution, 3, 257

SELWOOD, E. B., STEWART, I. J., TURNER, P. J. \& WHITELEY, M. J.

The Devonian-Carboniferous transition and its structural setting at Chillaton, West Devon, England, 4, 383

SOLIMAN, M. M.

Geochemical prospecting for $\mathrm{Cu}$ in Hamesh area, Southeastern Desert, Egypt, 3, 319

SUO, S., LIU, R. \& MA, X.

Interference fold patterns of the early Precambrian Rock Groups in the Songshan area, China, 5, 433

TALKINGTON, R. W., MAYEWSKI, P. A. \& GAUDETTE, H. E.

Geochemical and glacio-geomorphic implications of basalt weathering in the Queen Maud Mountains, Antarctica, 6, 553

THY, P. \& ESBENSEN, K. H.

Origin of fine-grained granular rocks in layered intrusions, 4, 405

TURNER, P., ASHWORTH, J. R. \& ISKENDERIAN, F. A.

Authigenic albite in the Pendleside Formation (Dinantian) of northern England, 4, 395

VEARNCOMBE, J. R.

The tectonic significance of Triassic dolomite and cargneule in the Gran Paradiso region, Western Alps, 3, 301

WADGE, G.

A Miocene submarine volcano at Low Layton, Jamaica, 2, 193

WATERHOUSE, J. B.

An early Permian cool-water fauna from pebbly mudstones in south Thailand, 4, 337

WOODCOCK, N. H. \& ROBERTSON, A. H. F.

Stratigraphy of the Mesozoic rocks above the Semail ophiolite, Oman, 1, 67

\section{CORRESPONDENCE}

DORNING, K. J. and LAWSON, J. D. Ludlow stratigraphy at Ludlow Shropshire, 6, 615

NAESER, C. W., TOGHILL, P.\& ROSS, R. J., JR. Fission-track ages from the Precambrian of Shropshire, 2, 213 
PARNELL, J. Genesis of the graphite deposit at Seathwaite in Borrowdale, Cumbria, 5, 511

SCOTT, S. C. Evidence from Longonot Volcano, Central Kenya, lending further support to the argument for a coexisting $\mathrm{CO}_{2}$ rich vapour in peralkaline magma, 2, 215

\section{ESSAY REVIEW}

HARLAND, W. B. Arctic Tectonics, 6, 619

\section{REVIEWS}

Advances in X-Ray Analysis, 4, 421

Andros Island, Chalk and oceanic oozes. Unpublished work of Maurice Black, 1, 102 Bibliography of Fossil Vertebrates 1978, 1, 105

Computer Applications in the Earth Sciences. An update of the 70s, 5, 518

Coniston Copper Mines, 5, 520

Developments in Petroleum Geology, 6, 633

Die Schwankungen der Grindelwaldgletscher in den historischen Bildund Schrift quellen des 12 bis 19 Jahrhunderts, 1, 104

Earthquake Mechanics, 4, 423

The Earth's Variable Rotation: Geophysical Causes and Consequences, 2, 219

Eastern England from the Tees to the Wash. British Regional Geology, 2, 221

Elementary Statistics Tables, 2, 224

Environmental effects of Offshore Oil Production. The Buccaneer Gas and Oil Field Study, 3, 326

Exploring the Unknown, 1, 101

Facies Interpretation and the Stratigraphic Record, 5, 517

Fossil Vertebrates of Alabama, 2, 222

Future Trends in Geomathematics, 6, 634

Geodesy, 2, 221

The Geological Survey of Ireland Bulletin, 3, 328

Geology and Water. An introduction to Fluid Mechanics for Geologists, 2, 222

The Geology of Libya, 2, 224

Geology of the country around Bellingham, 4, 422

Geology of the country around Faversham, 5, 519

Geology of the country around Penrith, 5, 514

GeoRef Thesaurus and Guide to Indexing. Third edition, 6, 639

History of Paleozoic Salt Accumulation, 5, 519

Hugh Miller. Outrage and Order. A biography and selected writings, 5, 521

Ichthyosaurus: a history of fossil 'sea-dragons', 2, 225

Lithostratigraphic Analysis of Sedimentary Basins, 1, 101

Lower Palaeozoic of the middle East, Eastern and Southern Africa, and Antarctica, 4, 427 
A Manual of New Mineral Names, 4, 421

Microfossils from Recent and Fossil Shelf Seas, 6, 634

Microtextures des Roches Magmatiques et Métamorphiques, 1, 102

Mineral Deposits and Global Tectonic Settings, 6, 638

Mineralogy for Students, 5, 513

Modern Igneous Petrology, 4, 428

Mountains and Man, 2, 224

Nannofossiles calcaires des Schistes Carton (Toarcien inférieur) du Bassin de Paris, 3, 329

The Nature of the Stratigraphical Record, 5, 522

Orogenic Andesites and Plate Tectonics, 5, 516

Paleobotany. An Introduction to Fossil Plant Biology, 3, 329

Phanerozoic Stromatolites, 3, 325

Phylogenetic Patterns and the Evolutionary Process. Method and Theory in Comparative Biology, 1, 103

The pre-glacial Pleistocene of the Norfolk and Suffolk coasts, 1, 105

Report on a Reconnaissance Radiometric Survey of the Irish Republic, 4, 428

Scanning Electron Microscopy and X-Ray Microanalysis, 6, 637

Scientific Basis for Nuclear Waste Management, 3, 327

Seismic Waves and Sources, 4, 426

Soils and Landforms, 4, 426

Soviet Journal of Remote Sensing, 5, 515

The Spindle Stage: Principles and Practice, 3, 325

The Stratigraphy of Foraminifera of the Upper Pleistocene in the Kola Peninsula, 3, 331 Systematic Index of Recent and Pleistocene Planktonic Foraminifera, 6, 636

Terrain Analysis and Remote Sensing, 4, 425

Transactions of the Royal Society of Edinburgh, 5, 513

The Turolian Fauna from the Island of Samos, Greece, 4, 424

Vicariance Biogeography - A critique, 4, 423

Wallace's line and Plate Tectonics, 6, 637

\section{Publications Received}

Lists appear beginning pages 1,$109 ; 2,226 ; 3,333 ; 4,431 ; 5,524 ; 6,641$

\section{Notices}

Notices from the International Commission on Zoological Nomenclature occur on pages, 1,$112 ; 4,430 ; 5,526 ; 6,642$ 


\section{Index}

to Authors, key words in titles and to new taxa and new stratigraphical terms in Volume 119; (R) indicates Review

Africa (R), 427

Afu Younger Granite Complex, 39

Alabama (R), 222

Albite, 395

Alexander Island, 291

Algae, 309

Alkaline igneous rocks, 497

Alps, 301

Ammonoidea, 95

Analysis, Rb-Sr, 599

Andesites (R), 516

Andros Island (R), 102

Antarctica, 291; 553; (R), 427

Apatite, 487

Appin, 413

Arctic, 619

Arcticoceras harlandi sp.nov., 98

?Arctitreta percostata sp.nov., 341

Arctocephalitinae, 95

Arionthia sapa sp.nov., 347

Arndt, N. T. \& Campbell, I. H. Pyroxene accumulation in spinifex-textured rocks, 605 Ashgill Series, 57

Ashworth, J. R., Turner, P. \& Iskenderian, F. A. Authigenic albite in the Pendleside Formation (Dinantian) of northern England, 395

Australia, 229

Authigenic, 395

Basalt weathering, 553

Bassett, M. G., Owens, R. M., Fortey, R. A., Cope, J. C. W. \& Rushton, A. W. A. Tremadoc faunas from the Carmarthen district, South Wales, 1

Bassett, M. G., Ross, R. J. Jr, Naeser, C. W., Izett, G. A., Obradovich, J. D., Hughes, C. P., Cocks, L. R. M., Dean, W. T., Ingham, J. K., Jenkins, C. J., Rickards, R. B., Sheldon, P. R., Toghill, P., Whittington, H. B. \& Zalasiewicz, J. Fission-track dating of British Ordovician and Silurian stratotypes, 135

Bassin de Paris (R), 329

Basu, A., Gupta, A. \& Ghosh, P. K. Ultramafic volcaniclastics of the Precambrian Dalma Volcanic Belt, Singhbhum, Eastern India, 505

Baulking, 487

Bellingham (R), 422

Benkhelil, J. Benue Trough and Benue Chain, 155

Benue Chain, 155

Benue Trough, 155

Berkshire, 487

Bibliography (R), 105 
Biogeography (R), 423

Biostratigraphy, 269

Biotite, 487

Blacknell, C. Morphology and surface sedimentary features of point bars in Welsh gravel-bed rivers, 181

Borrowdale, 511

Bovids (R), 424

Brachiopods, 371

Bradshaw, M. J. \& Penny, S. R. A cored Jurassic sequence from north Lincolnshire, England: stratigraphy, facies analysis and regional context, 113

British, 135

Brück, P. M., O'Connor, P. J., Hennessy, J. \& Williams, C. T. Abundance and distribution of uranium and thorium in the northern units of the Leinster granite, Ireland, 581

Buccaneer Field (R), 325

Calcareous algae, 309

Caledonian, 169; 413

Caledonides, 599

Calymene quadrata, 57

Cambrian, 611

Cambridgeshire, 593

Campbell, I. H. \& Arndt, N. T. Pyroxene accumulation in spinifex-textured rocks, 605

Cancrinelloides monticulus sp.nov., 344

Cape Flattery, 229

Carbonate marine-sands, 567

Carboniferous, 383

Cargneule, 301

Carmarthen, 1

Chalk (R), 102

Chapman, A. J., Rickards, R. B. \& Crowther, P. R. Ultrastructural studies of graptolites a review, 355

China, 433

Chlorite-mica stacks, 243

Chowdhury, A. N. Smectite, zeolite, biotite and apatite in the Corallian (Oxfordian) sediments of the Baulking area in Berkshire, England, 487

Clayton, C. J. \& Holdaway, H. K. Preservation of shell microstructure in silicified brachiopods from the Upper Cretaceous Wilmington sands of Devon, 371

Clough, B. J., Wright, J. V. \& Walker, G. P. L. Morphology and dimensions of the young comendite lavas of La Primavera volcano, Mexico, 477

$\mathrm{CO}_{2}, 215$

Cocks, L. R. M., Ross, R. J. Jr, Naeser, C. W., Izett, G. A., Obradovich, J. D., Bassett, M. G., Hughes, C. P., Dean, W. T., Ingham, J. K., Jenkins, C. J., Rickards, R. B., Sheldon, P. R., Toghill, P., Whittington, H. B. \& Zalasiewicz, J. Fission-track dating of British Ordovician and Silurian stratotypes, 135

Comendite lavas, 477

Comley, 611

Comparative Biology (R), 103

Computer Applications (R), 518

Coniston (R), 520 
Cope, J. C. W., Owens, R. M., Fortey, R. A., Rushton, A. W. A. \& Bassett, M. G. Tremadoc faunas from the Carmarthen district, South Wales, 1

Copper Mines (R), 520

Corallian, 487

Costacadoceras, gen.nov., 96; bluethgeni sp.nov., 97

Craig, J., Fitches, W. R. \& Maltman, A. J. Chlorite-mica stocks in low-strain rocks from central Wales, 243

Cretaceous, 291; 371

Crowther, P. R., Rickards, R. B. \& Chapman, A. J. Ultrastructural studies of graptolites a review, 355

$\mathrm{Cu}, 319$

Cumbria, 511

Dalma Volcanic Belt, 505

Dean, W. T., Ross, R. J. Jr, Naeser, C. W., Izett, G. A., Obradovich, J. D., Bassett, M. G., Hughes, C. P., Cocks, L. R. M., Ingham, J. K., Jenkins, C. J., Rickards, R. B., Sheldon, P. R., Toghill, P., Whittington, H. B. \& Zalasiewicz, J. Fission-track dating of British Ordovician and Silurian stratotypes, 135

Devon, 371

Devonian, 383

Diamictites, 527

Dinantian, 395

Dolomite, 301

Donovan, S. K. \& Paul, C. R. C. Lower Cambrian echinoderm plates from Comley, Shropshire, England, 611

Dorning, K. J. Ludlow stratigraphy at Ludlow, Shropshire, 615

Dyke swarm, 169

Earthquake (R), 423

Earth Sciences (R), 518

Earth's rotation (R), 219

Echinoderm plates, 611

Egypt, 319

Elasmata retusus gen. et sp.nov., 349

Electron microscopy (R), 637

Elliott, G. F. Calcareous algae and Middle Jurassic facies of southern England, 309

England, 113;201; 309; 315;383; 395; 487; 593; 611;(R), 221 ; Southwest, 567

Environmental effects (R), 325

Esbensen, K. H. \& Thy, P. Origin of fine-grained granular rocks in layered intrusions, 405

Estuaries, 567

Evans, A. H., Green, C. P. \& McGregor, D. F. M. Development of the Thames drainage system in Early and Middle Pleistocene times, 281

Evolutionary Process (R), 103

Exploring (R), 101

Fabiania, 257

Facies, Analysis, 113; Interpretation (R), 517; Jurassic, 309

Farnham, 315

Faversham (R), 519

Feldspathic quartzite, 413

Fisher, P. \& Rolls, J. D. A thermokarst phenomenon on a terrace of the River Wey near Farnham, Surrey, England, 315 
Fission-track ages, 213; dating, 135

Fitch, F. J., Kokelaar, B. P. \& Hooker, P. J. A new K-Ar age from uppermost Tremadoc rocks of north Wales, 207

Fitches, W. R., Craig, J. \& Maltman, A. J. Chlorite-mica stacks in low-strain rocks from central Wales, 243

Fluid Mechanics (R), 222

Fold Patterns, 433

Foraminifera, $201 ; 257 ;(\mathrm{R}), 331 ;(\mathrm{R}), 636$

Fortey, R. A., Owens, R. M., Cope, J. C. W., Rushton, A. W. A. \& Bassett, M. G. Tremadoc faunas from the Carmarthen district, South Wales, 1

Fossil Plant Biology (R), 329

Fossil Leaves, 291

Fossil Shelf Seas (R), 634

Fossil Vertebrates (R), 105; (R), 222

French, C. A. I. An analysis of the molluscs from an Ipswichian interglacial river channel deposit at Maxey, Cambridgeshire, England, 593

Garnets, 599

Gaudette, H. E., Talkington, R. W.\& Mayewski, P. A. Geochemical and glacio-geomorphic implications of basalt weathering in the Queen Maud Mountains, Antarctica, 553

Geochemical, 553; prospecting, 319

Geochemistry, 39

Geodesy (R), 221

Geology, (R), 222; 422; Faversham (R), 519; Libya (R), 224; 428; Penrith (R), 514

Geomathematics (R), 634

GeoRef (R), 639

Ghosh, P. K., Gupta, A. \& Basu, A. Ultramafic volcaniclastics of the Precambrian Dalma Volcanic Belt, Singhbhum, Eastern India, 505

Glacio-geomorphic, 553

Glen Coe, 169

Glen Creran, 169

Global Tectonic Settings (R), 638

Grampian Highlands, 169

Granite, 581

Granitic rocks, 39

Gran Paradiso, 301

Granular rocks, 405

Graphite deposit, 511

Graptolites, 355

Gravicalymene arcuata sp.nov., 62

Gravicalymene pontilis sp.nov., 61

Greece, 77; (R), 424

Green, C. P., McGregor, D. F. M. \& Evans, A. H. Development of the Thames drainage system in Early and Middle Pleistocene times, 281

Guide GeoRef (R), 639

Gupta, A., Basu, A. \& Ghosh, P. K. Ultramafic volcaniclastics of the Precambrian Dalma Volcanic Belt, Singhbhum, Eastern India, 505

Hamash area, 319

Hambrey, M. J. Late Precambrian diamictites of northeastern Svalbard, 527

Hampshire Basin, 463 
Harland, W. B. Arctic Tectonics, 619

Heavy minerals, 463

Hecla Hoek, 269

Hennessy, J., O’Connor, P. J., Brück, P. M.\& Williams, C. T. Abundance and distribution of uranium and thorium in the northern units of the Leinster granite, Ireland, 581

Holdaway, H. K. \& Clayton, C. J. Preservation of shell microstructure in silicified brachiopods from the Upper Cretaceous Wilmington Sands of Devon, 371

Hooker, P. J., Kokelaar, B. P. \& Fitch, F. J. A new K-Ar age from uppermost Tremadoc rocks of north Wales, 207

Hughes, C. P., Ross, R. J. Jr, Naeser, C. W., Izett, G. A., Obradovich, J. D., Bassett, M. G., Cocks, L. R. M., Dean, W. T., Ingham, J. K., Jenkins, C. J., Rickards, R. B., Sheldon, P. R., Toghill, P., Whittington, H. B. \& Zalasiewicz, J. Fission-track dating of British Ordovician and Silurian stratotypes, 135

Hugh Miller (R), 521

Humicretes, 229

Hyaenids (R), 424

Ichthyosaurs (R), 225

Igneous Petrology (R), 428

Igneous rocks, 497

Imeokparia, E. G. Geochemistry and relationships to mineralization of granitic rocks from the Afu Younger Granite Complex, Central Nigeria, 39

India, 257; eastern, 505

Indirect dating, 599

Ingham, J. K., Ross, R. J. Jr, Naeser, C. W., Izett, G. A., Obradovich, J. D., Bassett, M. G., Hughes, C. P., Cocks, L. R. M., Dean, W. T., Jenkins, C. J., Rickards, R. B., Sheldon, P. R., Toghill, P., Whittington, H. B. \& Zalasiewicz, J. Fission-track dating of British Ordovician and Silurian stratotypes, 135

Interference fold patterns, 433

Ipswichian interglacial, 593

Ireland, $581 ;(\mathrm{R}), 328 ; 428$

Iskenderian, F. A., Turner, P. \& Ashworth, J. R. Authigenic albite in the Pendleside Formation (Dinantian) of northern England, 395

Island of Samos (R), 424

Izett, G. A., Ross, R. J. Jr, Naeser, C. W., Obradovich, J. D., Bassett, M. G., Hughes, C. P., Cocks, L. R. M., Dean, W. T., Ingham, J. K., Jenkins, C. J., Rickards, R. B., Sheldon, P. R., Toghill, P., Whittington, H. B. \& Zalasiewicz, J. Fission-track dating of British Ordovician and Silurian stratotypes, 135

Jamaica, 193

Jefferson, T. H. The preservation of fossil leaves in Cretaceous volcaniclastic rocks from Alexander Island, Antarctica, 291

Jenkins, C. J., Ross, R. J. Jr, Naeser, C. W., Izett, G. A., Obradovich, J. D., Bassett, M. G., Hughes, C. P., Cocks, L. R. M., Dean, W. T., Ingham, J. K., Rickards, R. B., Sheldon, P. R., Toghill, P., Whittington, H. B. \& Zalasiewicz, J. Fission-track dating of British Ordovician and Silurian stratotypes, 135

Jenkins, D. G. The age and palaeoecology of the St Erth Beds, southern England, based on planktonic foraminifera, 201

Jurassic, 95; 113; 309

K-Ar age, 207; 497

Kenya, 215 
Knoll, A. H. Microfossil-based biostratigraphy of the Precambrian Hecla Hoek sequence, Nordaustlandet, Svalbard, 269

Kokelaar, B. P., Fitch, F. J. \& Hooker, P. J. A new K-Ar age from uppermost Tremadoc rocks of north Wales, 207

Kola Peninsula (R), 331

Komukia solita gen. et sp.nov., 343

Kong Karls Land, 95

Kotopouli, C. N., Pe-Piper, G., Panagos, A. G. \& Piper, D. J. W. The (?) mid Triassic volcanic rocks of Lakonia, Greece, 77

Landforms (R), 426

La Primavera volcano, 477

Lavas, 477

Lawson, J. D. Ludlow stratigraphy at Ludlow, Shropshire, 617

Layered intrusions, 405

Leinster granite, 581

Libya (R), 224

Lincolnshire, England, 113

Lippard, S. J. \& Rex, D. C. K-Ar ages of alkaline igneous rocks in the northern Oman mountains, NE Arabia, and their relations to rifting, passive margin development and destruction of the Oman Tethys, 497

Lithostratigraphic (R), 101

Liu, R., Suo, S. \& Ma, X. Interference fold patterns of the early Precambrian Rock Groups in the Songshan area, China, 433

Longonot volcano, 215

Ludlow, 615

Magma, 215

Magmatiques (R), 102

Maltman, A. J., Craig, J. \& Fitches, W. R. Chlorite-mica stacks in low-strain rocks from Central Wales, 243

Man (R), 224

Marine sands, 567

Ma, X., Suo, S. \& Liu, R. Interference fold patterns of the early Precambrian Rock Groups in the Songshan area, China, 433

Mayewski, P. A., Talkington, R.W. \& Gaudette, H. E. Geochemical and glacio-geomorphic implications of basalt weathering in the Queen Maud Mountains, Antarctica, 553

Merefield, J. R. Modern carbonate marine-sands in estuaries of southwest England, 567

Mesozoic, 67

Metamorphiques (R), 102

Mexico, 477

Microanalysis (R), 637

Microfossils (R), 634

Microtextures (R), 102

Middle East (R), 427

Mineral Deposits (R), 638

Mineralization, 39

Mineral Names (R), 421

Mineralogy (R), 513

Minor intrusions, 413

Miocene, 193 
Modern, 587

Molluscs, 593

Morton, A. C. Heavy minerals of Hampshire Basin Palaeogene strata, 463

Mountains (R), 224

McDougall, I. \& Ollier, C. D. Potassium-argon ages from Tristan da Cunha, South Atlantic, 87

McGregor, D. F. M., Green, C. P. \& Evans, A. H. Development of the Thames drainage system in Early and Middle Pleistocene times, 281

Naeser, C. W., Ross, R. J. Jr, Izett, G. A., Obradovich, J. D., Bassett, M. G., Hughes, C. P., Cocks, L. R. M., Dean, W. T., Ingham, J. K., Jenkins, C. J., Rickards, R. B., Sheldon, P. R., Toghill, P., Whittington, H. B. \& Zalasiewicz, J. Fission-track dating of British Ordovician and Silurian stratotypes, 135

Naeser, C. W., Toghill, P. \& Ross, R. J. Jr. Fission-track ages from the Precambrian of Shropshire, 213

Nannofossiles (R), 329

NE Arabia, 497

Nigeria, 39

Nordaustlandet, 269

Norfolk (R), 105

North Wales, 57

Nuclear Waste (R), 327

Obradovich, J. D., Ross, R. J. Jr, Naeser, C. W., Izett, G. A., Bassett, M. G., Hughes, C. P., Cocks, L. R. M., Dean, W. T., Ingham, J. K., Jenkins, C. J., Rickards, R. B., Sheldon, P. R., Toghill, P., Whittington, H. B. \& Zalasiewicz, J. Fission-track dating of British Ordovician and Silurian stratotypes, 135

Oceanic oozes (R), 102

O'Connor, P. J., Hennessy, J., Brück, P. M. \& Williams, C. T. Abundance and distribution of uranium and thorium in the northern units of the Leinster granite, Ireland, 581

Offshore Oil (R), 325

Ollier, C. D. \& McDougall, I. Potassium-argon ages from Tristan da Cunha, South Atlantic, 87

Oman, 67; mountains, 497

Ophiolite, 67

Ordovician stratotypes, 135

Owens, R. M., Fortey, R. A., Cope, J. C. W., Rushton, A. W. A. \& Bassett, M. G. Tremadoc faunas from the Carmarthen district, South Wales, 1

Oxfordian, 487

Palaeoecology, 201

Palaeogene, 463

Palaeozoic (R), 427

Paleobotany (R), 329

Paleozoic (R), 519

Panagos, A. G., Pe-Piper, G., Piper, D. J. W. \& Kotopouli, C. N. The (?) mid Triassic volcanic rocks of Lakonia, Greece, 77

Parnell, J. Genesis of the graphite deposit at Seathwaite in Borrowdale, Cumbria, 511

Partial melting, 413

Passive margin, 497

Paul, C. R. C. \& Donovan, S. K. Lower Cambrian echinoderm plates from Comley, Shropshire, England, 611 
Pendleside Formation, 395

Penney, S. R. \& Bradshaw, M. J. A cored Jurassic sequence from north Lincolnshire, England: stratigraphy facies analysis and regional context, 113

Penrith (R), 514

Pe-Piper, G., Panagos, A. G., Piper, D. J. W. \& Kotopouli, C. N. The (?) mid Triassic volcanic rocks of Lakonia, Greece, 77

Peralkaline magma, 215

Permian, 337

Petroleum Geology (R), 633

Petrology (R), 429

Phanerozoic (R), 325

Phylogenetic Patterns (R), 103

Piper, D. J. W., Pe-Piper, G., Panagos, A. G. \& Kotopouli, C. N. The (?) mid Triassic volcanic rocks of Lakonia, Greece, 77

Planktonic Foraminifera (R), 636

Plate Tectonics (R), 516; 637

Platten, I. M. A late Caledonian breccia dyke swarm in Glen Creran, near Glen Coe in the Grampian Highlands, 169

Platten, I. M. Partial melting of feldspathic quartzite around late Caledonian minor intrusions in Appin, Scotland, 413

Pleistocene, 281; (R), 105; (R), 331

Pleistocene Foraminifera (R), 636

Point bars, 181

Potassium-argon ages, 87

Precambrian, $213 ; 269 ; 433 ; 505 ; 527$

Preservation, $291 ; 371$

Price, D. Calymene quadrata King, 1923 and allied species of trilobites from the Ashgill Series of North Wales, 57

Production, offshore oil (R), 325

Pye, K. Characteristics and significance of some humate-cemented sands (humicretes) at Cape Flattery, Queensland, Australia, 229

Pyroxene, 605

Queen Maud Mountains, 553

Rawson, P. F. New Arctocephalitinae (Ammonoidea) from the Middle Jurassic of Kong Karls Land, Svalbard, 95

$\mathrm{Rb}-\mathrm{Sr}, 599$

Recent Foraminifera (R), 636

Recent Shelf Seas (R), 634

Remote Sensing (R), 425; 515

Rex, D. C. \& Lippard, S. J. K-Ar ages of alkaline igneous rocks in the northern Oman mountains, NE Arabia, and their relations to rifting, passive margin development and destruction of the Oman Tethys, 497

Reymer, A. P. S. Indirect dating of tectonic events by Rb-Sr analysis of syntectonic garnets: an example from schists of the Seve Nappe, Central Scandinavian Caledonides, 599

Rhynchopora culta sp. nov., 345

Rickards, R. B., Crowther, P. R. \& Chapman, A. J. Ultrastructural studies of graptolites a review, 355

Rickards, R. B., Ross, R. J. Jr, Naeser, C. W., Izett, G. A., Obradovich, J. D., Bassett, M. G., Hughes, C. P., Cocks, L. R. M., Dean, W. T., Ingham, J. K., Jenkins, C. J., 
Sheldon, P. R., Toghill, P., Whittington, H. B. \& Zalasiewicz, J. Fission-track dating of British Ordovician and Silurian stratotypes, 135

Rifting, 497

River channel deposit, 593

Rivers, gravel-bed, 181

River Wey, 315

Robertson, A. H. F. \& Woodcock, N. H. Stratigraphy of the Mesozoic rocks above the Semail ophiolite, Oman, 67

Rocks, 243; 605

Rolls, J. D. \& Fisher, P. A thermokarst phenomenon on a terrace of the River Wey near Farnham, Surrey, England, 315

Ross, R. J. Jr, Naeser, C. W., Izett, G. A., Obradovich, J. D., Bassett, M. G., Hughes, C. P., Cocks, L. R. M., Dean, W. T., Ingham, J. K., Jenkins, C. J., Rickards, R. B., Sheldon, P. R., Toghill, P., Whittington, H. B. \& Zalasiewicz, J. Fission-track dating of British Ordovician and Silurian stratotypes, 135

Ross, R. J. Jr, Naeser, C. W. \& Toghill, P. Fission-track ages from the Precambrian of Shropshire, 213

Royal Society of Edinburgh (R), 513

Rushton, A. W. A., Owens, R. M., Fortey, R. A., Cope, J. C. W. \& Bassett, M. G. Tremadoc faunas from the Carmarthen district, South Wales, 1

Salt (R), 519

Samanta Bimal K. Fabiania Silvestri (Foraminiferida) from India, with notes on its global distribution, 257

Sands, 229

Scandinavian Caledonides, 599

Scanning Electron Microscopy (R), 637

Schistes Carton (R), 329

Schists, 599

Schwankungen der Grindelwaldgletscher (R), 104

Scotland, 413

Scott, S. C. Evidence from Longonot volcano, Central Kenya, lending further support to the argument for a coexisting $\mathrm{CO}_{2}$-rich vapour in peralkaline magma, 215

Seathwaite, 511

Sedimentary Basins (R), 101

Sediments, 487

Seismic, waves and sources (R), 426

Seismology (R), 423

Selwood, E. B., Stewart, I. J., Turner, P. J. \& Whiteley, M. J. The Devonian-Carboniferous transition and its structural setting at Chillaton, West Devon, England, 383

Seve Nappe, 599

Sheldon, P. R., Ross, R. J. Jr, Naeser, C. W., Izett, G. A., Obradovich, J. D., Bassett, M. G., Hughes, C. P., Cocks, L. R. M., Dean, W. T., Ingham, J. K., Jenkins, C. J., Rickards, R. B., Toghill, P., Whittington, H. B. \& Zalasiewicz, J. Fission-track dating of British Ordovician and Silurian stratotypes, 135

Shelf Seas (R), 634

Shell microstructure, 371

Shropshire, $213 ; 611 ; 615$

Silurian stratotypes, 135

Singhbhum, 505 
Smectite, 487

Soils (R), 426

Soliman, M. M. Geochemical prospecting for $\mathrm{Cu}$ in Hamash area, Southeastern Desert, Egypt, 319

Songshan, 433

South Atlantic, 87

South Wales, 1

Soviet (R), 515

Spindle Stage (R), 325

Spinifex-textured, 605

Statistics (R), 224

St Erth Beds, 201

Stewart, I. J., Selwood, E. B., Turner, P. J. \& Whiteley, M. J. The Devonian-Carboniferous transition and its structural setting at Chillaton, West Devon, England, 383

Stratigraphical Record (R), 522

Stratigraphic Record (R), 517

Stratigraphy, Ludlow, 615; Lincolnshire, 113; Oman, 67; (R), 331

Stromatolites (R), 325

Submarine volcano, 193

Suffolk (R), 105

Suo, S., Liu, R. \& Ma, X. Interference fold patterns of the early Precambrian Rock Groups i in the Songshan area, China, 433

Svalbard, 95; 269; 527

Syntectonic, 599

Talkington, R. W., Mayewski, P. A. \& Gaudette, H. E. Geochemical and glacio-geomorphic implications of basalt weathering in the Queen Maud Mountains, Antarctica, 553

Tectonic events, 599

Tectonics, 619

Tectonic Settings (R), 638

Tees (R), 221

Terrain Analysis (R), 425

Tethys, 497

Thailand, 337

Thames drainage system, 281

Thermokarst phenomenon, 315

Thesaurus GeoRef (R), 639

Thorium, 581

Thy, P. \& Esbensen, K. H. Origin of fine-grained granular rocks in layered intrusions, 405

Toarcien (R), 329

Toghill, P., Naeser, C. W. \& Ross, R. J. Jr. Fission-track ages from the Precambrian of Shropshire, 213

Toghill, P., Ross, R. J. Jr, Naeser, C. W., Izett, G. A., Obradovich, J. D., Bassett, M. G., Hughes, C. P., Cocks, L. R. M., Dean, W. T., Ingham, J. K., Jenkins, C. J., Rickards, R. B., Sheldon, P. R., Whittington, H. B. \& Zalasiewicz, J. Fission-track dating of British Ordovician and Silurian stratotypes, 135

Tremadoc, North Wales, 207; South Wales, 1

Triassic, 77; 301

Trilobites, 57

Tristan da Cunha, 87 
Turner, P., Ashworth, J. R. \& Iskenderian, F. A. Authigenic albite in the Pendleside Formation (Dinantian) of northern England, 395

Turner, P. J., Selwood, E. B., Stewart, I. J. \& Whiteley, M. J. The Devonian-Carboniferous transition and its structural setting at Chillaton, West Devon, England, 383

Turolian Fauna (R), 424

Ultramafic volcaniclastics, 505

Ultrastructural studies, 355

Uranium, 581

Vearncombe, J. R. The tectonic significance of Triassic dolomite and cargneule in the Gran Paradiso region, Western Alps, 301

Vertebrates (R), 222

Volcanic, 77

Volcaniclastic rocks, 291

Volcaniclastics, 505

Volcano, submarine, 193

Wadge, G. A Miocene submarine volcano at Low Layton, Jamaica, 193

Wales, 207; 243

Walker, G. P. L., Clough, B. J. \& Wright, J. V. Morphology and dimensions of the young comendite lavas of La Primavera volcano, Mexico, 477

Wallace's line (R), 637

Wash (R), 221

Water (R), 222

Waterhouse, J. B. An early Permian cool-water fauna from pebbly mudstones in south Thailand, 337

Welsh gravel-bed rivers, 181

West Devon, 383

Whiteley, M. J., Selwood, E. B., Stewart, I. J. \& Turner, P. J. The Devonian-Carboniferous transition and its structural setting at Chillaton, West Devon, England, 383

Whittington, H. B., Ross, R. J. Jr, Naeser, C. W., Izett, G. A., Obradovich, J. D., Bassett, M. G., Hughes, C. P., Cocks, L. R. M., Dean, W. T., Ingham, J. K., Jenkins, C. J., Rickards, R. B., Sheldon, P. R., Toghill, P. \& Zalasiewicz, J. Fission-track dating of British Ordovician and Silurian stratotypes, 135

Williams, C. T., O'Connor, P. J., Hennessy, J. \& Brück, P. M. Abundance and distribution of uranium and thorium in the northern units of the Leinster granite, Ireland, 581

Wilmington Sands, 371

Woodcock, N. H. \& Robertson, A. H. F. Stratigraphy of the Mesozoic rocks above the Semail ophiolite, Oman, 67

Wright, J. V., Clough, B. J. \& Walker, G. P. L. Morphology and dimensions of the young comendite lavas of La Primavera volcano, Mexico, 477

X-Ray Analysis (R), 421

X-Ray Microanalysis (R), 637

Zalasiewicz, J., Ross, R. J. Jr, Naeser, C. W., Izett, G. A., Obradovich, J. D., Bassett, M. G., Hughes, C. P., Cocks, L. R. M., Dean, W. T., Ingham, J. K., Jenkins, C. J., Rickards, R. B., Sheldon, P. R., Toghill, P. \& Whittington, H. B. Fission-track dating of British Ordovician and Silurian stratotypes, 135

Zeolite, 487 


\section{NOTES FOR CONTRIBUTORS}

Contributions for publication should be addressed to The Editors, Geological Magazine, Department of Earth Sciences, Downing Street, Cambridge CB2 3EQ, England.

All contributions, whether articles, correspondence or reviews, must be typed in duplicate on one side of the paper, double spaced throughout, with a wide margin on the left of each page and a narrower margin on the right. Any minor corrections should be made neatly in the typescript, leaving the margins clear.

The total length of a paper should not in general exeeed 20 pages of the Geological Magazine; preference and priority are given to short papers. Longer papers (between 20 and 40 pages of Geological Magazine) will from time to time be considered, but authors wishing to submit such manuscripts should first request further details.

The accuracy of references is the responsibility of authors. References must be double spaced and abbreviated in the form of the World List of Scientific Periodicals 4 th Edition as far as possible, e.g.

Brooks, M. \& James, D. G. 1975. The geological results of seismic refraction surveys in the Bristol Channel, 1970-73. Q. Jl geol. Soc. Lond. 131, 163-82.

Kirby, G. A. 1978. Layered gabbros in the Eastern Lizard, Cornwall, and their significance. Geol. Mag. 115, 199-204.

Books should be cited as:

Ramsey, J. G. 1967. Folding and Fracturing of Rocks. New York: McGraw-Hill.

Bott, M. H. P. 1973 The evolution of the Atlantic north of the Faroe Islands. In Implications of Continental Drift to the Earth Sciences, vol. 1 (ed. D. H. Tarling and S. N. Runcorn), pp. 175-89. London, New York: Academic Press.

Unpublished work, e.g. from theses, should normally be referred to in the text in parentheses and not included in the reference list unless in the press.

Articles must be accompanied by a brief summary. Contributions should follow the general style of papers in recent issues of the Magazine and the principles laid down in Notes to Authors (Proc. Geol. Soc. Lond., No. 1627. Oct. 1965). Headings should be set out clearly, but not underlined. Primary headings should be in lower case, at margin, with arabic numeral; sub-headings should be numbered 2.a, 2.b, etc., and tertiary headings 2.a.1., 2.a.2. No cross-references should be given by page number, but 'above' and 'below' should be used with the section specified, e.g. Section 2.a.1.

Illustrations must be drawn to allow reduction to maximum size of $200 \mathrm{~mm} \times$ $134 \mathrm{~mm}$; originals should normally be drawn at twice final size and must be sent in a flat package. Lettering must allow for legibility after reduction (i.e. equivalent to $1 \mathrm{~mm}$ as a minimum on reduction). Duplicates of illustrations may be prints or, preferably, reductions. Metric units of the SI system are preferred. Illustrations in the text will be referred to as figures (Fig. 2, $2 a$, etc.), and halftone plates will be referred to (also in arabic) as Plates 2, $2 a$, etc. Folding plates will not be accepted. Captions for figures and plates must be typed on separate sheets.

Twenty-five offprints of each paper will be provided free of charge. Additional offprints may be purchased according to a set scale of charges. 


\section{Geological Magazine}

\section{Volume 119, Number 6, November 1982}

HAMBREY, M. J.

Late Precambrian diamictites of northeastern Svalbard

$527-55^{1}$

TALKINGTON, R. W., MAYEWSKI, P. A. \& GAUDETTE, H. E,

Geochemical and glacio-geomorphic implications of basalt weathering in the

$553-566$

Queen Maud Mountains, Antarctica

MEREFIELD, J. R.

Modern carbonate marine-sands in estuaries of southwest England

$567-580$

O'CONNOR, P. J., HENNESSY, J., BR U'CK, P. M. \& WILLIAMS, C. T,

Abundance and distribution of uranium and thorium in the northern units of the

$5^{81}-59^{2}$

Leinster granite, Ireland

FRENCH, C. A. I.

An analysis of the molluses from an Ipswichian interglacial river channel deposit

$593-59^{8}$

at Maxey, Cambridgeshire, England

REYMER, A. P. S.

Indirect dating of tectonic events by $\mathrm{Rb}-\mathrm{Sr}$ analysis of syntectonic garnets:

$599-604$

an example from schists of the Seve Nappe, central Scandinavian Caledonides

CAMPBELL, I. H. \& ARNDT, N. T.

Pyroxene accumulation in spinifex-textured rocks

$605-610$

DONOVAN, S. K. \& PAUL, C. R. C.

Lower Cambrian echinoderm plates from Comley, Shropshire, England

$611-614$

CORRESPONDENCE

Ludlow stratigraphy at Ludlow, Shropshire:

K. J. DORNING and J. D. LAWSON

$615-618$

ESSAY REVIEW

W. B. HARLAND

$619-631$

Arctic Tectonics

REVIEWS

PUBLICATIONS RECEIVED $\quad 641$

$633-639$

NOTICE

(C) Cambridge University Press 1982

Printed in Great Britain at the University Press, Cambridge 